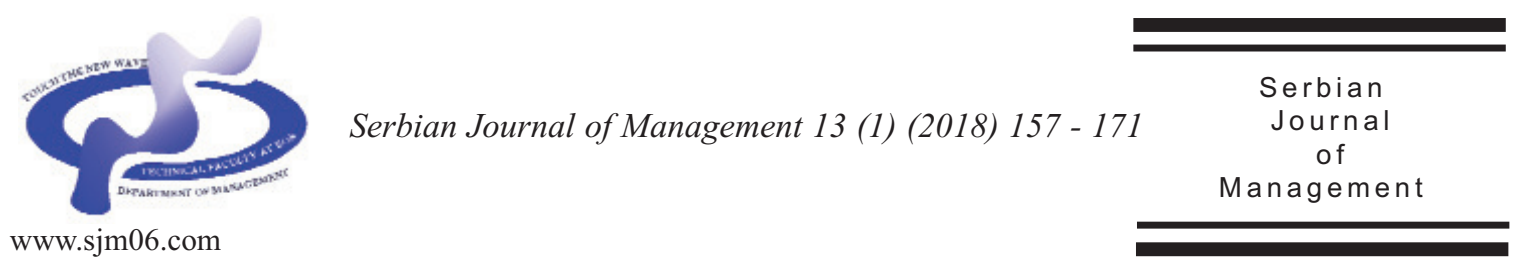

\title{
A NEW EVALUATION METHOD OF LOCAL MUSCULAR LOAD AT WORKPLACES IN CZECH COMPANIES
}

\author{
Barbora Dombeková* and David Tucek
}

Tomas Bata University in Zlín, nám. T.G. Masaryka 5555, Zlín, 760 01, Czech Republic

(Received 9 January 2017; accepted 5 September 2017)

\begin{abstract}
In this article, the role and position of Ergonomics, Local Muscular Load Measuring, wac defined. There are two main parts of ergonomics: overall physical load and local muscle load. The measurement methods based on using muscle forces are used in the Czech Republic mainly. Other countries measure local muscular load more subjectively, through evaluation sheets (ergonomic checklists). However, in this article, the presented methods are more precise and objective. Otherwise, the employee risks exposure to occupational diseases, serious illnesses, etc. In this case, the employer is then exposed to liabilities stemming from not creating suitable working conditions, such as compensation, increased recruitment costs, etc. In the Czech Republic, management is increasingly being held liable for occupational diseases stemming from "local muscular load" of employees. In the world, it is also known as the repetitive strain injury (RSI). As a result, it is necessary to evaluate the local muscular load in Czech businesses and identify the main causes of overload. In this article, the authors will introduce a new methodology for local muscular load measuring with the datalogger equipment. The research also showed that the health and safety limits for local muscular load were exceeded in $52 \%$ of the workplaces researched. Various causes and weaknesses were identified. These could increase those risks.
\end{abstract}

Key words: workplace, ergonomics, carpal tunnel syndrome, electromyography, datalogger, longterm, excessive and unilateral overload, Repetitive Strain Injury (RSI), job rotation

\section{INTRODUCTION}

We are at the beginning of Industry 4.0. Industry 4.0 is the next phase in digitalization of the manufacturing sector. Most of the digital technologies have been brewing for some time. Some are not yet ready for application at scale. However, for this next industrial revolution, Big Data and Analytics, Autonomous Robots, Simulation, etc. are typical. But what about human factor? What about position of operators?

\footnotetext{
* Corresponding author: dombekova@fame.utb.cz
}

DOI: $10.5937 / \mathrm{sjm} 13-12884$ 
Despite a growing trend of automation and robotics, the human factor remains important. It is therefore essential to create healthy and supportive working conditions. Ergonomics supports a human factor position. "It is the discipline concerned with the understanding of interactions among humans and other elements of a system, and the profession that applies theory, principles, data and methods to design in order to optimize human well-being and overall system performance" (IEA, 2015).

In the Czech and Slovak Republic, the EMG measurement is a standard method of diagnosing the carpal tunnel syndrome. When doing medical examination of the nerve through the carpal tunnel, a lower sensitivity as well as prolonged distal motor latency occurs. Moreover, a dispersion of potentials is often revealed. If suffering from severe disorders, a lower number of amplitudes of a summing operational potential is typical. According to the values measured, we quantify and stratify the seriousness of disorder in the field of neurography. In the Czech Republic, there is the Standard of Electrophysiological Carpal Tunnel Syndrome Diagnosis effective for the purposes of reporting on occupational diseases (Minks et al., 2014).

The aim of the paper is to evaluate the "local muscular load" that is measured in Czech businesses mainly, and verification of the local muscular load measuring methodology as a valid and recognized measurement in order to subsequently strengthen injury prevention of occupational diseases among workers. The illnesses caused by local muscular load are the most frequent occupational diseases in the Czech Republic. Among them, occupational carpal tunnel syndrome (CTS) is the most frequent one. Minks et al. (2014) note that "Carpal tunnel syndrome is the most common mononeuropathy and the most common occupational disease".

The paper presents theoretical and experimental evaluation of the developed equipment (datalogger) and its validation with the existing certified methodology called electromyography (EMG).

\section{ERGONOMICS AND REPETITIVE STRAIN INJURY}

It is rather common that Czech and Slovak managers do not know what they should focus on in their activities regarding ergonomics. In the ergonomics theory, we can see different opinions on the discipline of ergonomics.

Ergonomics is a science that deals with human characteristics and behaviour in the working process affected by the working environment, by using the working tools, machines, etc. (McCormick, 1982). Dul and Ceylan (2011) perceive ergonomics as an effective way to "prevent and correct negative effects of the way of organizing work". Neglecting ergonomic aspects in the system development can lead to serious human errors (Pavlovic-Vasilinovic, 2014).

For two main reasons, ergonomics and its programs should be required in all corporate processes. The first reason is that companies follow the ergonomic principles only when they are required by legislation or business market (Karwowski, 1998). The second reason is that in today's economy, workers are the most worthwhile resource of any organization (Kohn \& Friend, 1993). Ergonomics believes that the human body is limited by range of motion, speed, endurance and strength; therefore, the goal of ergonomics is to evaluate the person, work 
environment and working task and then attempt to meet the worker's needs (Alnaser, 2009). The results of ergonomics are obvious in elimination of negative influences in the work environment, maximizing human health, comfort and well-being. The increasing interest in ergonomics can be also attributed to cost reductions stemming from reducing work-related injuries, occupational diseases (Rowan \& Wright, 1995), and absenteeism, while at the same time improving the employee's productivity, job satisfaction, and loyalty. At the same time, suitable ergonomic solution is the way to success and product profitability (Fisher et al., 2009). The most significant risk factors are physical factors (microclimate, vibrations, noise, lighting, etc.), chemical substances and mixtures, physical stress, psychological stress and visual stress (Cesko, 2007). One of the factors of physical stress is the "local muscular load," a load on small muscle groups during the work performance of the upper limbs (Cesko, 2007). It is the involvement of fingers, hands and forearms while working. Most often, the local muscular load is developed by a work characterized by fine motor skills, monotony, work in unsuitable working positions of the upper limbs or by the presence of other factors (cold, vibration, etc.). The local muscular load is also viewed as a long-term, excessive and unilateral overload. In the world literature, the term of local muscular load (used in the Czech Republic) is known as Repetitive Strain Injury (RSI).

It is a compressive neuropathy in the wrist that occurs as a result of long-term, excessive and unilateral overload of the hand and wrist, due to vibration transmission to the hand, etc. CTS is caused by compression of nerve in wrist (see Fig. 1). This compression gives rise to the typical symptoms of CTS: numbness, tingling, hand weakness, etc. (Mayoclinic, 2015). Every tenth Czech and even $30 \%$ of workers at risk professional groups are affected by CTS (Academy Spectrum, 2013).

Other diseases caused by local muscular load are epicondylitis, arthrosis, tendovaginitis, morbus de Quervain and other entrapment syndromes.

CTS is a fairly common nerve entrapment in the upper limb not only in the Czech Republic. For example, in Dutch general population between the age of 25 and 74, the

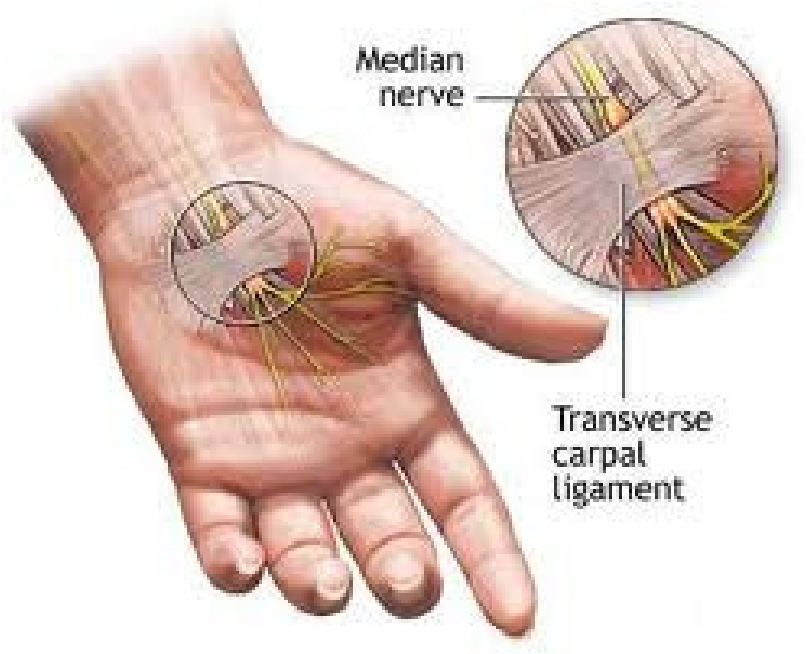

Figure 1. Carpal tunnel syndrome (Simon, 2012) 
prevalence of CTS based on typical symptoms and abnormal nerve conduction in the median nerve at the carpal tunnel was 9.2 $\%$ among women $(5.8 \%$ had undetected CTS and 3.4\% had the disorder diagnosed earlier) and $0.6 \%$ among men. In the NorthAmerican general population study, the incidence of first occurrence of CTS based on visits to a doctor was estimated at 3.5 cases per 1,000 person-years. (ViikariJuntura \& Silverstein, 1999).

\section{RESEARCH METHODS}

The basic prerequisite for detecting the level of ergonomics is the identification of key risk factors. One of the worst risks is that of local muscular load. A high level of knowledge and expertise is required from the evaluator in order to accurately determine local muscular load in workplaces. The risks and risk factors it is also possible to simulate by SW tools as e.g. ARIS (Tuckova \& Tucek, 2010; Závadský \& Závadská, 2014). This not only requires knowledge of anatomy and physiology, but also practical knowledge and experience with this type of assessment. The evaluator must be familiar with the issues, know how to properly apply the measuring instrument and competently evaluate the results. When the risk identification is complete, evaluation (objectification), interpretation, management and monitoring are required.

\subsection{Company selection criteria}

The process of identifying and evaluating the risks was carried out in a selected number of companies in the Czech Republic. Companies were selected following the predefined criteria:
- Companies operating in regions with a higher incidence of occupational diseases caused by physical factors, in particular, Chapter II, items 9 and 10 (Annex of Government Regulation No. 290/1995 Coll., as amended), and namely in the MoravianSilesian Region and Olomouc;

- Companies with over 250 employees with a higher reported incidence of occupational diseases;

- Companies in which professions are carried out which fall under the classifications CZ-ISCO 72 (metalworkers, machine-building labourers and related workers), CZ-ISCO 75 (food, wood and textile processors and workers in related trades), CZ-ISCO 81 (stationary plant and equipment), CZ-ISCO 82 (assembly workers for products and equipment).

\subsection{Criteria for workplace selection}

The workplaces in which the study was carried out were subsequently selected according to the following criteria:

- work performed by women statistics regarding occupational diseases suggest that occupational diseases due to long-term, excessive and unilateral overload (illness tendons, tendon sheaths, ligaments, muscles, peripheral nerves, joints and diseases bursae of pressure) are the most common in the case of women;

- work that does not require a worker to have a certain lateralization (i.e. the work can be performed by right-handers and lefthanders without affecting quality) - righthanders were chosen for the purposes of being able to make a valid object comparison because the greater part of the population is right-handed;

- work operations that require the use of the upper limbs, whereby local muscular 
load is the load on the upper limbs;

- $\quad$ work that involves both upper limbs in order to provide the same measurement conditions for all measured work activities;

- $\quad$ work that involves minimal handling of loads, whereby the emphasis is on work performed by small muscle groups;

- $\quad$ work characterized by monotony;

- work with a forced work pace.

\subsection{Integrated electromyography as a measuring method}

After identifying the risk factors in the workplace, an evaluation (objectification) followed. The evaluation was carried out with the use of integrated electromyography (EMG) to generate standardized measurements. In the Czech Republic, the EMG method is the only officially recognized method for measuring local muscular load, and only the authorized companies can carry out measurements.

The expended muscle strength, the number of movements and the operating position of the limbs are identified and verified during the evaluation of local muscular load, depending on the extent of the static and dynamic parts of a person's work during an average eight-hour shift.

The EMG method has been widely used in the past years to investigate central fatigue, by evaluating responses of the central nervous system (i.e. changes in the motor unit recruitment). The methods for measuring can vary a little, especially during prolonged maximal voluntary contraction (MVC), whereby the EMG amplitude decreases progressively in parallel with the force output (Bigland-Ritchie et al., 1983; Sirin \& Patla, 1987; Hatzikotoulas et al., 2004). Conversely, during submaximal contractions, whereby the EMG amplitude progressively increases in order to retain the force output (Fuglevand et al., 1993; Gamet \& Maton, 1989; Lascher et al., 1996).

Other methods exist around the world measuring muscular activity, e.g. surface electromyography (sEMG). A portable EMG system (MyoGuard) was used to collect myoelectrical signals on-line and analyse them using a computer (Rolander et al., 2005).

Some articles confirm that it is possible to decrease local muscular load in factories by using mini-load multi-shuttle Automated Storage and Retrieval Systems (AS/RS) and discrete event simulation. The simulation model for multi-shuttle AS/RS consists of two lines (single depth) of Storage Racks (SR), an SR machine, Input and Output locations (I/O Location), and other manipulation equipment (Lerher et al., 2011).

However, for typical measurements of local muscular load in the Czech Republic (to obtain the values and type of expended muscular strength of extensors and flexors of the forearm of both upper limbs of a measured person), non-invasive electromyography was carried out using a Holter EMG. The Holter EMG (i.e. data collection station) is shown in Figure 2.

As Figure 3 shows, five electrodes were placed on both upper limbs to scan the muscle activity. Two electrodes were located on the extensors, two on the flexors and one ground electrode on the tendon in the elbow.

Prior to taking measurements, it was necessary to individually determine the maximum muscle strength for each upper limb. Each limb was put into a predetermined position (upper arm parallel to the body, with the forearm held at a right angle). The highest activity of electrical potential was recorded as 100\% Fmax for 


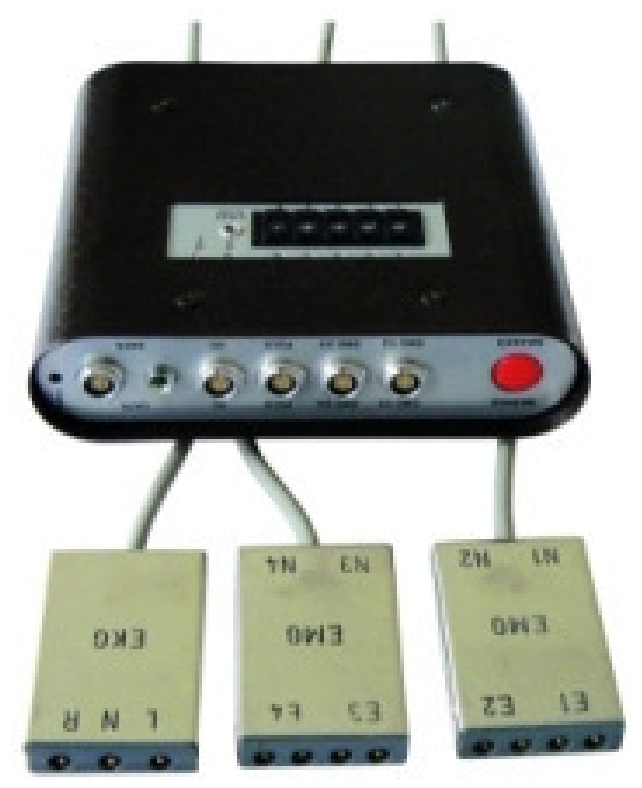

Figure 2. Holter EMG (Gadourek, 2010)

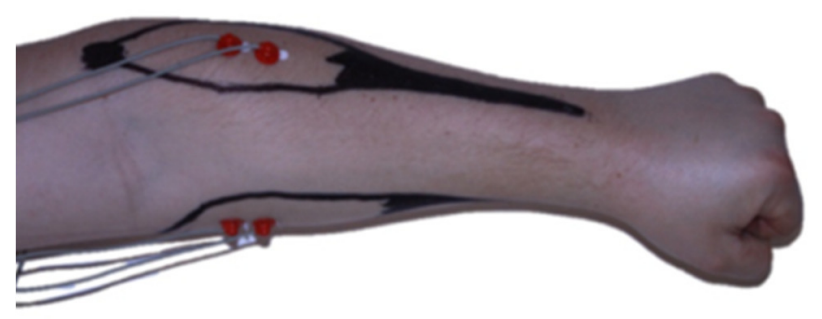

Figure 3. EMG electrodes placed on the arm (own processing)

measuring the muscle groups of the flexors and extensors of the forearm.

With special software (see Figure 4), it was possible to evaluate individual EMG signals, separate them in time, calculate the average expended muscle forces ( $\%$ Fmax), show the frequency analysis of individual muscle forces (0-100\% Fmax), etc.

The analysis of repetitive movements through video analyses the number of movements of hand and forearm. It was determined for each upper limb separately.
This was done directly in the workplace, or later through the analysis of audio-visual recordings made during the monitored work. The obtained values were time-weighted per average work shift, based on the time frame or the number of finished products (the real performance, standard).

An adequately prepared and trained worker is an important prerequisite for successful measurements. In addition, workers were required not to have any medical or other limitations that would cause 


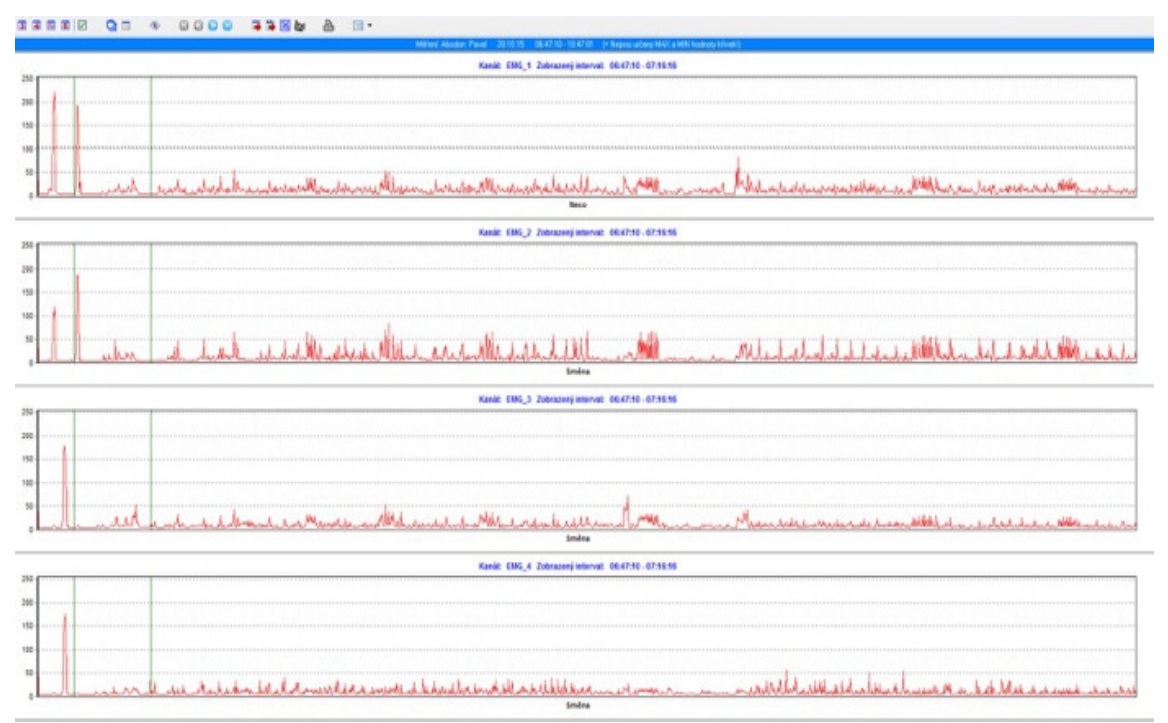

Figure 4. Output from the Holter EMG (own processing)

the non-physiological involvement of the locomotor apparatus of the upper limbs. The worker also had to be right-handed and meet the anthropometric criteria of the average population.

\subsection{Evaluation of the risk factor}

After the measurements were taken, the risk factors associated with local muscular load were evaluated (objectified). The evaluation of the measured results was carried out by comparing them to the health and safety limits specified in $\$ 25$ of Government Decree No. 361/2007 Coll., as amended. The health and safety limits for local muscular load are represented by the value of the expended muscle strength; the number of movements of the hand and forearm during the shift (these movements are relative to the average shift timeweighted value for expended muscle strength); and the average minute counts of movements of small muscles of hand and fingers in an average eight-hour shift (Cesko, 2007).
The determination of work as being hazardous or non-hazardous was based on whether the work in question complied with or exceeded the legally stipulated health and safety limits. Figure 5 presents the health and safety limits in relation to the mean average muscle strength relative to the permitted number of movements. A part of the reference curve (graphically illustrated health and safety limits), whereby the values under the curve are perceived to be nonhazardous (sub-limit) and the values above the curve are perceived to be hazardous (over-limit). Under current health and safety legislation, the limit is determined as $53 \%$ Fmax.

\section{NEW MEASURING DEVICE - DATALOGGER}

The invention is an ergonomic device monitoring local muscle strain. The device can be usable at workplaces with a higher muscle strain, mainly the one of arms when having frequent/repetitive motions often 


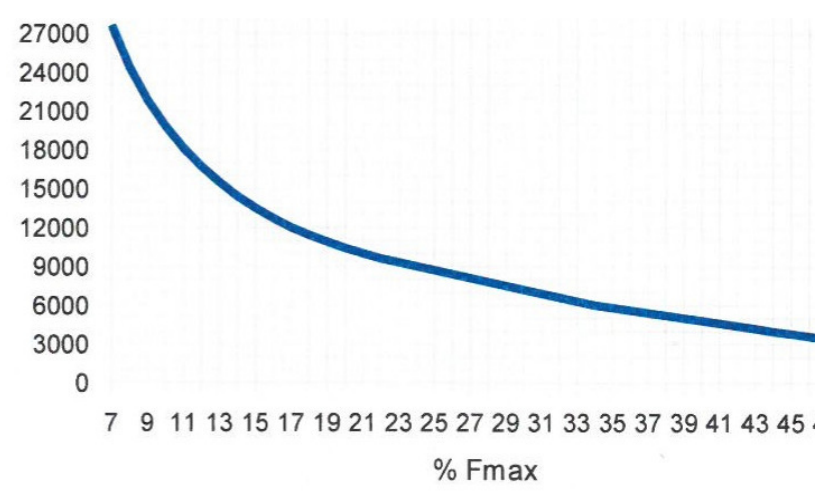

Figure 5. Health and safety limits in graph (Cesko, 2007)

connected with higher muscle strength. These are particularly workplaces of assembly, but also of other type as well.

Within this project, so-called Measuring device consisting of Datalogger and measuring gloves was designed and tested. Altogether, four functional samples of Datalogger and measuring gloves were made. The practical use can be seen in Figure 8.

Then, a methodology to measure local muscle strain of employees of manufacturing as well as non-manufacturing companies was suggested. These strains are mainly caused by tunnel syndromes, e.g. carpal tunnel syndrome. A follow-up programme application that forms an integral part of the methodology was prepared. This application enables users of the measuring device (Datalogger and measuring gloves) to have a simple and clear measurement output, in the form of graph as well, without having deep knowledge of statistical methods.

The development of this device underwent at workplaces of Tomas Bata University in Zlín and Department of Cybernetics and Biomedical Engineering at VŠB - Technical University of Ostrava following standard procedures of $\mathrm{HW}$ development in the following stages.

- Design and construction of $1 \mathrm{st}$ measuring device iteration

- Implementation of 1 st iteration and operating SW

- $\quad$ Testing of 1 st iteration

- Error correction and construction of 2nd HW iteration

- Harmonizing SW for 2nd HW iteration

\subsection{Brief description of Datalogger device - design and construction}

Datalogger is a small compact device recording data from the sensors attached.

Legend to Figure 6. - Device description:

1 Batteries 4 AA, 1,5 V

2 Backup

3 Measuring gloves connector

4 Battery - to back up real time. It is necessary to set the time again when changing it.

5 Micro SD card slot

6 Backup

7 Measuring gloves connector

$8 \mathrm{ON}$ and OFF button

9 External power supply connector

10 RESET button (reserved) 


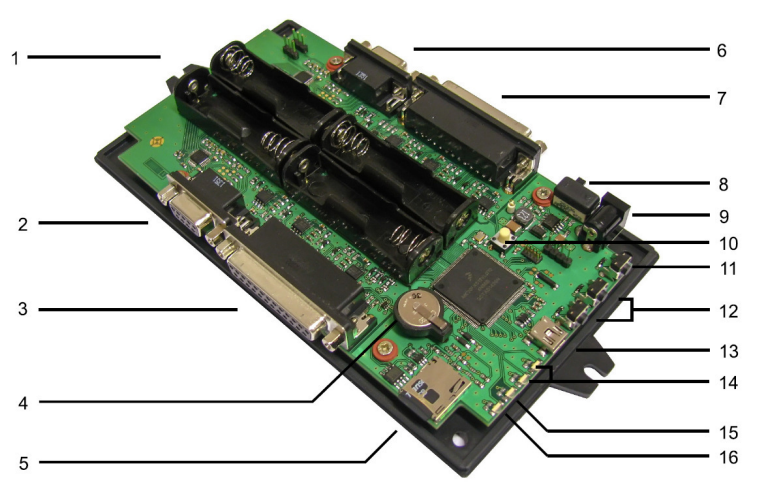

Figure 6. Device description (own processing)

$11 \mathrm{ON}$ and OFF button - storage medium entry.

12 Time symbols button (markers)

13 USB interface

14 Connected glove indication

15 Backup

16 Power supply indicator (light is on) / entry indicator (it flashes)

\section{MEASURED PARAMETERS OF NEW METHODS}

The principal comparative metric of both types of measurements (EMG and Datalogger) is strength. At present, the only method used for measuring local muscle strain is the method of integrated electromyography (EMG). At the same time, it is the most accurate method available that is in accordance with legislation of the Czech Republic, Government Decree No. 361/2007 Coll., which sets occupational health and safety rules, as subsequently amended. By using this method, we monitor the reaction/response of neuromuscular system (neuromuscular activity of an employee) to a particular workload. In the course of this measurement, the electrophysiological bio potentials from particular muscles of arms and forearms are recorded. These are groups of flexors and extensors (muscles) on each arm. The result of the measurement is percentage of muscle strength needed derived from maximum strength of flexors and extensors on each arm. In the text, it is described as \% Fmax. The EMG Holter device does the measurement. A tension meter or dynamometer is used to measure maximum muscle strength of an employee.

Based on \% Fmax found and the calculation of number of motions (done by reading from video) including the frequency analysis, particular work becomes part of a certain category. When breaking occupational health rules, specific precautions must be taken. A part of the evaluation is making decision on a predominant element of work in the sense of dynamic-static strain.

The output from EMG measurements is stating \% Fmax for particular muscles per work shift. This means a muscle activity of flexors and extensors on forearms.

This fact led us to the construction of device which would be able to measure the muscle activity not on the forearm, but directly on the hand of an employee, i.e. fingers and palms, thus to study a muscle activity that can cause suffering from the 
tunnel syndromes (carpal tunnel syndrome, etc.) when breaking occupational health rules. The aim was to invent a device measuring the strength used right on the place where the motion starts, i.e. fingers and palms. The output of this device is information about the average strength used - in Newton units. In the future, this userfriendly device can contribute to prevention as well as elimination of tunnel syndromes, when namely the carpal tunnel syndrome is the most frequent job-related illness in the Czech Republic.

\section{RESULTS OF RESEARCH}

The research showed that the health and safety limits for local muscular load was exceeded in $52 \%$ of the measured workplaces. A number of causes and weaknesses were identified. These could increase those risks. The increased risks may cause a subsequent increasing trend in the incidence of occupational diseases especially carpal tunnel syndrome. The most striking causes and effects are presented in this section.

\subsection{Low level of ergonomics}

All the workplaces were evaluated ergonomically as poor. The basic principles of ergonomics were implemented to a limited extent in the workplaces and administrative processes, if at all. With regard to local muscular load, the following shortcomings were identified: unsuitable height of the working plane; oppression of the upper limbs caused by the edge of the worktop; unacceptable working position of the upper limbs (wrist rotation, radial or ulnar deviation); uneconomic movements, unilateral overload of fingers while using the working tools, etc.

In addition to the deficiencies related to local muscle load, other deficiencies were identified in the built-up area of the foot, and in workplaces where employees were not provided with an ergonomic pad or appropriate seating with regard to back support and working position (especially the neck and upper limbs).

It was discovered that some other cofactors are involved in the occurrence of local muscular load. The presence of the following co-factors was evaluated within this research: improper working position, cold, vibrations and oppression. The presence of co-factors was discovered in 24 cases, i.e. $29.6 \%$ of the total number of measured workplaces. The composition of the co-factors was as follows (see Figure 7):

This graph shows that the most significant co-factor affecting local muscular load is an improper working position, which was observed in $62 \%$ of cases.

The relationship to the average forces used was researched through statistical tests against hypotheses on the impact of the cofactors, i.e. in relation to $\%$ Fmax. The ANOVA test was applied for this purpose (analysis of dispersion).

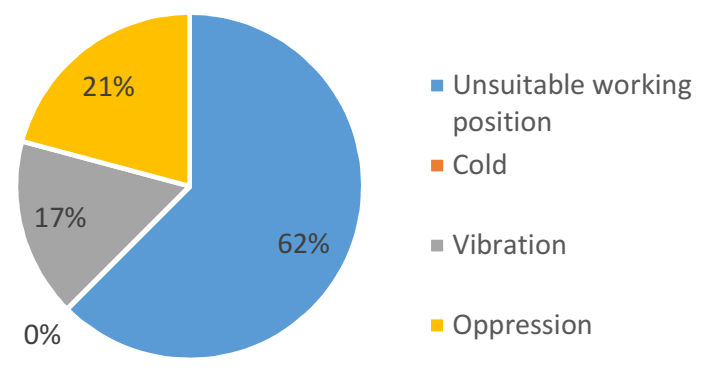

Figure 7. Presence of co-factors (own processing) 
The prerequisite for this test were different levels of the average forces developed for operations in which the cofactor was acting unlike those that did not contain the cofactor. The zero hypothesis asserts that the influence of the cofactor is insignificant. Against stands the alternative hypothesis with the opposite statement. As seen from the descriptive views of distribution of average forces in \% Fmax, it can be assumed that the average forces in cofactor operations (in red) are higher (see Figure 8).

The ANOVA test (see Figure 9), both in its parametric version and in the nonparametric analogy of the Kruskal-Wallis test (see Figure 10), rejected the zero hypothesis due to $p$-values $<0.001$. Thanks to this evidence of the statistically significant influence of the cofactor presence on average forces, the \% Fmax was found.

The prerequisites for this test were different levels of the average forces used during operations where the co-factor had an impact, in comparison to those that did not include the co-factor.

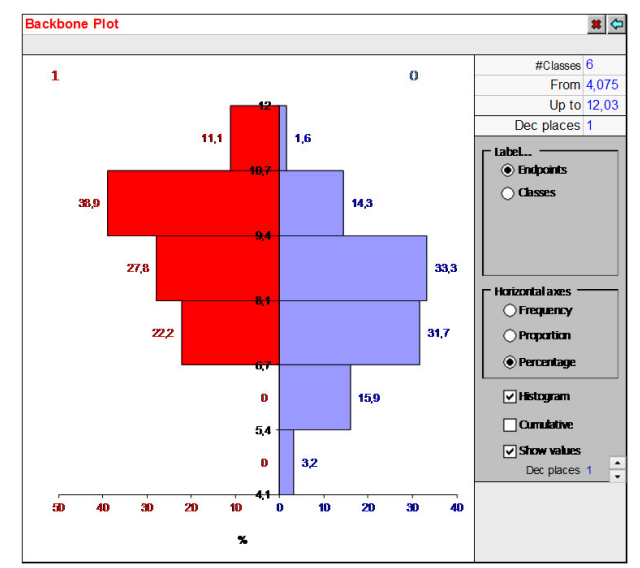

Figure 8. Distribution of average muscular forces in co-factor / no co-factor operations (own processing)

\begin{tabular}{|c|c|c|c|c|}
\hline \multicolumn{5}{|c|}{$\begin{array}{l}\mathrm{H}_{0} \text { : All population means (of F-PRUMER) are equal } \\
\mathrm{H}_{1} \text { : Not all population means (of F-PRUMER) are eq }\end{array}$} \\
\hline \multicolumn{5}{|c|}{$\mathrm{p}$-value $=0,00023$} \\
\hline \multicolumn{5}{|c|}{ ANOVA Table } \\
\hline Source & $\mathrm{DF}$ & $\overline{S S}$ & $\mathrm{MS}$ & F \\
\hline kofaktor & 1 & 30,8534 & 30,8534 & 14,8591 \\
\hline Error & 79 & 164,036 & 2,0764 & \\
\hline Total & 80 & 194,889 & & \\
\hline
\end{tabular}

Figure 9. Output of the program XLStatistics: ANOVA test (own processing)

\begin{tabular}{|l|l|}
\hline Kruskal-Wallis test & జ \\
$\mathrm{H}_{0}:$ All population medians equal \\
$\mathrm{H}_{1}$ : Not all populations medians equal \\
\hline $\mathrm{H} 11,53710156$ \\
\hline p-value $=0,000682209$ \\
\hline
\end{tabular}

Figure 10. Output of the program XLStatistics: Kruskal-Wallis test (own processing)

\subsection{Other measures to eliminate local muscular load}

A significant number of women who took part in the research were middle-aged, i.e. 40 -50 . It was assumed that the occurrence of occupational diseases due to local muscular load would be higher in this group due to the onset of the menopause. Carpal tunnel syndrome often occurs when there is a change in the hormonal balance (menopause). Some of the important measures that can be taken to tackle the issue in this group include preventive medical examinations (more intensive monitoring of health status), a planned health program or defined rehabilitation.

There are numbers of other measures which could contribute to elimination of the risks mentioned. For example: ergonomic workplace design; optimization of technological and operating procedures; 
introduction of new technologies; removal of the need for frequent handling of loads by technological means; involving workers in the system of improvements and adaptation of workplaces and operating procedures; training workers with respect to proper operating procedures; decreasing the workload or performance requirements of a worker; safety breaks according to valid legislation (5 - 10 minutes every 2 hours); relaxation exercises, e.g. during safety breaks. The ergonomic principles can also bring many other benefits as mentioned in the theoretical part of this work.

The index methods represent a recommended complementary component for measuring the risk of local muscular load, during the evaluation of unacceptable working positions in particular. As previously mentioned, a working position is one of the co-factors that have an impact on the level of risk of local muscular load. We mainly use the index methods RULA and REBA (Kee \& Karwowski, 2007). The results of applying such methods can be a comprehensive picture of workplace risks.

\section{CONCLUSION}

Local muscular load is one of the main causes of occupational diseases in the Czech Republic. This applies in particular to the load on the upper limbs during work performance, so-called local muscular load. The disease most prevalent in the Czech Republic because of long-term, excessive and unilateral overload is the carpal tunnel syndrome. The results of this research show that more than $50 \%$ of the measured workplaces exceed the health and safety limits concerning the risk of local muscular load.
The results of the performed analysis regarding the main causes of the occurrence of local muscular load show that poor ergonomic design is one of the most significant factors. Employers fail to either implement ergonomic principles, or they only implement them to a very limited extent. Furthermore, local muscular load is affected by the presence of co-factors (vibrations, unacceptable working position, cold and oppression). Statistical tests proved dependence between the presence of cofactors and higher applied myodynamia. Last but not least, there was evidence of the insufficient integration of job rotation into operational processes. As a result of this failure, there is an increased risk of exceeding the health and safety limits for employees and employers alike, which can result in lots of problems and increased costs. A number of remedial measures were put forward through which an employer can potentially eliminate the risk of local muscular load or reduce it to a significantly lower level. If ergonomics and the principles of ergonomics are applied to the corporate processes within a company, the risk of the occurrence of health problems of workers and the associated costs for work injuries or occupational diseases can be decreased.

In the context of our new methodology of Local Muscular Measurement, we started with measuring by EMG and datalogger in laboratory conditions first. We implemented the trainee tasks with more than 150 responders.

We did measurements for about 10 companies in the Czech Republic (it is more than 50 operations and the correlation rate (R2) between the results is again very high: between $0.7-0.9$.

We see certain limitations of this research and the measurement methods which can be 
used. Firstly, the measurement methods based on using muscle forces are used in the Czech and Slovak Republic mainly. Other countries measure local muscular load more subjectively, through evaluation sheets (ergonomic checklists). However, the presented methods are more precise and objective. Secondly, there are no limits to categorize the measured results as hazardous or non-hazardous in terms of risks to human health. Currently, the law has set limits for the EMG measurements. Meanwhile, the limits for the datalogger are not determined and the approval process is very lengthy and difficult. The last limitation is in an inadequate testing of datalogger in real conditions of production companies. This fact is linked with our plan to test the datalogger in other real conditions to have new results for further research. A new challenge of our research is using the datalogger while assessing the level of multiple sclerosis when a patient's force used is evaluated.

\section{Acknowledgements}

The author is thankful to the Internal Grant Agency of FaME TBU No. IGA/FaME/2015/030 (Evaluation model of ergonomic principles in Czech companies) and Internal Grant Agency of FaME TBU No. RO/2014/03, VaV-IP-RO/2015/03-Ch (Modelling of parameters of efficient production and administrative processes in industrial companies based on the concept of Industry 4.0) for financial support to carry out this research.

\section{References}

Alnaser, M. (2009). Ergonomics. Work, 34 (2), 131-132.

Bigland-Ritchie, B., Johanson, R., Lippold, OC., \& Woods, JJ. (1983). Contractile speed and EMG changes during fatigue of sustained maximal voluntary contractions. Journal of Neurophysiology, 50 (1), 313-324.

Cesko. Narizeni vlady č. 361/2007 Sb., kterym se stanovi podminky ochrany zdravi při praci. In Sbirka zakonu ČR, rocnik 2007, castka 111. Available from: $<$ http:/www.zakonyprolidi.cz/cs/2007-361> [cit. 2015-11-09]. ISSN 1211-1244.

Definition and Domains of ergonomics. 2015. International Ergonomics Association (IEA) [online]. [cit. 2015-11-18]. Available from: http://www.iea.cc/whats/index.html

Diseases and Conditions: Carpal tunnel syndrome. Mayoclinic [online]. 2015. Florida. [cit. 2015-11-19]. Available from: http://www.mayoclinic.org/diseasesc ondition s/ c a r p a $1-t$ un n e 1 syndrome/basics/definition/con-20030332

Dul, J., \& Ceylan, C. 2011. Work environments for employee creativity. Ergonomics, 54 (1), 12-20.

Fisher, K., Hobelsberger, C., \& Zink, K.J., (2009). Human Factors and Sustainable Development in Global Value Creation. In: IEA (Ed.): 17 th World Congress on Ergonomics of IEA 2009. Bejing, CN: IEA Press.

Fuglevand, AJ., Zackowski, KM., Huey, KA., \& Enoka. RM. (1993). Impairment of neuromuscular propagation during human fatiguing contractions at submaximal forces. The Journal of Physiology, 460, 549-572

Gadourek, P., \& Lebeda. T. (2010). Ergonomická laborator: Mereni a hodnoceni lokalni svalove zateze metodou integrovane 


\title{
НОВА МЕТОДА ЕВАЛУАЦИЈА ЛОКАЛНОГ МИШИЋНОГ ОПТЕРЕЪЕЊА НА РАДНИМ МЕСТИМА У ЧЕШКИМ КОМПАНИЈАМА
}

\author{
Barbora Dombeková, David Tucek
}

\section{Извод}

У овом чланку дефинисана је улога и позиција ергономије, за локално мерење оптерећења мишића. Постоје два главна дела ергономије: укупна физичка оптерећења и оптерећење локалних мишића. Методе мерења, представљене у овом раду, засноване на коришћењу мишића користе се углавном у Чешкој Републици. У другим земљама се мерења локалног мишићног оптерећења врше углавном субјективно, кроз листе за оцену (ергономске контролне листе). Међутим, у овом чланку, представљене методе су прецизније и објективније. У супротном, радник ризикује изложеност професионалним болестима, озбиљним болестима итд. У том случају, послодавац се потом излаже обавезама које произилазе из стварања одговарајућих радних услова, као што су надокнада, повећани трошкови регрутовања итд. У Чешкој републици, менаџмент се све више сматра одговорним за професионалне болести које произилазе из "локалног мишићног оптерећења" запослених. У свету, то је познато и као повремена повреда (РСИ). Као резултат тога, неопходно је проценити локално мишићно оптерећење у чешким предузећима и идентификовати главне узроке преоптерећења. У овом чланку аутори ће представити нову методологију за мерење локалног мишићног оптерећења помоћу опреме за аквизициију података. Истраживање је такође показало да су границе здравља и сигурности за локално мишићно оптерећење прекорачене на $52 \%$ истраживаних радних места. Идентификовани су различити узроци и слабости. Ово истраживање би могло утицати на те ризике.

Кључне речи: радно место, ергономија, синдром карпалног тунела, електромиографија, регистратор података, дуготрајно, прекомерено и једнострано преоптерећење, понављајућа повреда стреса (РИС), ротација посла

elektromyografie. GETA Centrum s.r.o. [online]. GETA Centrum s.r.o. [cit. 2015-1031]. Available from: http://www.plm.automation.siemens.com/cz _cz/Images/Gadourek_a_tcm841117307.pdf

Gamet, D., \& Maton. B. (1989). The fatigability of two agonistic muscles in human isometric voluntary submaximal contraction:an MG study: I. Assessment of muscular fatigue by means of surface EMG. European Journal of Applied Physiology, 58, 361-368.
Hatzikotoulas, K., Siatras, K., Spyropoulou, T., Paraschos, E., \& Patikas. D. (2004). Muscle fatigue and electromyographic changes are not different in women and men matched for strength, European journal of applied physiology, 92 (3), 298-304.

Karwowski, W. (1998). Occupational Ergonomcs Handbook. Boca Raton, Florida, USA: CRC Press.

Kee, D., \& Karwowski. W. (2007). A Comparison of Three Observational Techniques for Assessing Postural Loads in 
Industry. International Journal of Sirin, A.V., \& Patla, A.E. (1987). Occupational Safety and Ergonomics, 13 (1), Myoelectric changes in the triceps surae 3-14.

Kohn, J. P., \& Friend, M. A. (1993). Quality and ergonomics: The team approach to the occupational people factor. Professional Safety, 36 (5), 39-42.

Lascher, WN., Cresswell, AG., \& Thorstensson. A. (1996). Central fatigue during a long lasting submaximal contraction of the triceps surae. Experimental Brain Research, 108 (2), 305-314.

Lerher, T., Sraml, M., \& Potrc. I. (2011). Simulation analysis of mini-load multishuttle automated storage and retrieval systems. International Journal of Advanced Manufacturing Technology, 54 (1-4), 337348.

McCormick, E.J., \& Sanders. M.S. (1982). Human Factors in engineering and design. New York, USA: McGraw-Hil.

Minks, E., \& Minksová A. Brhel P, Babičová V. (2014). Occupational carpal tunnel syndrome. Neurologie pro praxi, 15 (5), 234-237

Pavlovic-Veselinovic, S. (2014). Ergonomics as a missing part of sustainability. Work, 49 (3), 395-399.

Rolander, B., Jonker, D., Karsina, A., \& Öberg. T. (2005). Evaluation of muscular activity, local muscular fatigue, and muscular rest patterns among dentists, Acta Odontologica Scandinavica, 63, (4), 189195.

Rowan, M.P., \& Wright. P.C. (1995). Ergonomics is good for business. Facilities, $13,(8), 18-25$.

Simon, H. (2012). Carpal tunnel syndrome. University of Maryland medical center (UMM) [online]. Maryland, [cit. 2015-11-19]. Available from: https://umm.edu/health/medical/reports/artic les/carpal-tunnel-syndrome muscles under sustained contractions. European Journal of Applied Physiology, 56 (2), 238-244

Syndrom karpalniho tunelu. (2013). Academy Spectrum zdravi: Cesta do sveta zdravi a mediciny [online]. [cit. 2015-1203]. Available from: http://www.spektrumzdravi.cz/academy/syn drom-karpalniho-tunelu

Tuckova, Z., \& Tucek, D. (2010). Increasing knowledge by teaching of modern BPM systems. International Conference on Engineering Education and International Conference on Education and Educational Technologies-Proceedings. Corfu Island, Greece. 487-492.

Viikari-Juntura, E., \& Silverstein, B. (1999). Role of physical load factors in carpal tunnel syndrome. Scandinavian Journal of Work, Environment \& Health, 25 (3), 163-185.

Závadský, J., \& Závadská, Z. (2014). Utilisation of business process models in managerial practice: An empirical study in Slovak companies certified to the ISO 9001 standard, Total Quality Management and Business Excellence, 25 (3-4), 319-337. 